\title{
Playful Religion: An Innovative Approach to Prevent Radicalisation of Muslim Youth in Europe
}

\author{
Omer Gurlesin ${ }^{1}\left(\mathbb{D}\right.$, Muhammed Akdag $^{2}{ }^{(\mathbb{D}}$, Alper Alasag ${ }^{1}$ and Ina ter Avest ${ }^{3, *(\mathbb{C}}$ \\ 1 Islamitisch Kennis Cenrum (IKC), Laan op Zuid 129, 3072 DB Rotterdam, The Netherlands; \\ gurlesin@gmail.com (O.G.); alasag@gmail.com (A.A.) \\ 2 Independent researcher, 44267 Dortmund, Germany; akdagmuhammedm@gmail.com \\ 3 Z-in-gesprek, coaching\&consultancy, Ede 6711 PK, The Netherlands \\ * Correspondence: khteravest@gmail.com
}

Received: 26 September 2019; Accepted: 21 January 2020; Published: 31 January 2020

\begin{abstract}
Radicalisation of Muslim youth is a hot item in the Netherlands. Deradicalisation is therefore high on the agenda. In our view, however, the deradicalisation processes begin at a moment 'when it is too late to lock the stable door, because the horse has already bolted'. That is why our focus is on the prevention of radicalisation. In our contribution, we explore the concept of 'radicalisation' and inform the reader about deradicalisation programmes developed in the Netherlands and in Europe. The lack of success of these programmes challenges us to focus on 'prevention'. In our view, a playful dialogical encounter in a safe space is a must in the approach of young people who are on the verge of radicalisation. The above-mentioned concepts of radicalisation, deradicalisation and prevention are presented in the first paragraph, followed by a discussion of de- and counter-radicalisation programmes in paragraph two. The third paragraph focuses on the prevention of radicalisation in education. Crucial here is a dialogical relationship between teachers and students, between the students themselves and within the students' inner selves. This latter aspect is inspired by the theoretical framework of the dialogical self-theory, with its core concept of 'multi-voicedness' and 'positioning of voices'. Special attention in the positioning process is given to resilience. The heart of this publication is dedicated to the re-invention of an age-old Islamic game: shatranj al- 'arifin'. In the fourth paragraph, we describe its origins and our adapted version of this game. Playing the game in pilot studies—a 'serious play session'—increases young people's awareness of religion and its positioning, resulting in strengthening resilience in their life orientation. In the concluding fifth paragraph, we state that our innovative, playful and theoretically well-framed approach is a promising module to be implemented in formal and informal education.
\end{abstract}

Keywords: Islamic religious education; playfulness; pedagogical strategy; dialogical self-theory; prevention of radicalisation

\section{Introduction}

In the Netherlands, the radicalisation of Muslim youngsters is seen as an urgent problem. Muslim youngsters are seen as 'at risk'; youngsters who embrace extreme ideologies the very moment they feel driven into a corner and will not get any help from their parents, teachers or social worker (Sieckelinck 2017 , p. 21). The vast majority of youngsters with radical ideas never go over to violent actions (Laqueur, in Kundnani 2012, p. 8). However, an almost obsessive reaction of educators and policy makers is de-radicalisation. The question however is: is this the one and only possible responses, taking into account that, so far, no proof is given for the effectiveness of these programs (Coolsaet 2019). In his publication 'Radicaliseren; Ronselen voor een betere wereld' (Radicalisation; press-ganging for a better world), the philosophic educator Stijn Sieckelinck explores the possibilities for the prevention of 
radicalisation. His starting point is the idealist views and an urge for radical positioning of youngsters, their needs in the sometimes disturbing process of identity development ${ }^{1}$ (Wiktorowicz, in: Kundnani 2012, p. 17), their strong feelings for justice, their fighting spirit, their search for moral authority and last but not least the aspect of 'rites de passage', with all these being characteristics for the age group concerned (Sieckelinck 2017, p. 51). Inspired by Sieckelinck's line of thought and provoked by his expression of 'roots and wings', our focus became the prevention of radicalisation of 'youngsters at risk' by way of strengthening 'roots' and creating space for stretching their 'wings'.

Via the understanding of the concept of radicalisation, its context bound process, the de-radicalisation programs and the theoretical frame work of the dialogical self-theory (DST; Hermans and Hermans-Konopka 2010) we arrive at a playful space for further development of 'roots and wings'.

\section{The Concept of Radicalisation}

In order to prevent radicalisation, it is important to learn more about the genesis of this process. Even more important, it seems, is to know what is understood by 'radical' and 'radicalisation'. The 'Expert Group on Violent Radicalisation' established by the European Commission states that: '[r]adicalisation is a context-bound phenomenon par excellence. Global, sociological and political drivers matter as much as ideological and psychological ones' ${ }^{2}$. This description is in line with Walter Laqueur's individual and group dynamic approach ${ }^{3}$ (in: Kundnani 2012, p. 10). From this, we learn that radicalisation is not a characteristic of an object (radical change), nor a process to which someone is (passively) subjected (... causing someone to adapt), but a result of the interactionality of a variety of factors (global, sociological and political drivers; ideological and psychological drivers). 'Radical' seems to be a relative concept. The concept gets its meaning and its impact from its position in relation to mainstream religiosity, political commitment or social activities in the context a person lives in. In the western context the understanding of 'radical' more and more was and still is shaped "by the demand of counter-terrorist policy makers rather than an attempt to objectively study how terrorism comes into being" (ibid., p. 5). A demand rooted in an urge for an early warning system.

Moreover, circles of friendship and other groups a person belongs to or wishes to participate in seem to constitute a fertile context for radicalisation (Sageman, in: Kundnani 2012, p. $14 \mathrm{ff}$ ). Social bonds, in Sageman's view, "come before any ideological commitment' (in: Kundnani 2012, p. 15). His theory is known as the "bunch of guys"-theory. Rooted in the theories of Sageman and Wiktorowicz, four stages are mentioned in the process of radicalisation: pre-radicalisation, self-identification, indoctrination and jihadisation These stages are considered to function as a pathway to violent extremism (Kundnani 2012, p. 18). In an interesting comment, Oliver Roy offers another perspective. In his view theology and violence should be separated from eachother. In his view, the leap into violence is not motivated by religion, but is a multifaceted problem (in: Kundnani 2012, p. 21); a ball of complexity, to be disentangled in close cooperation with theological and social scientists and practitioners. Our work is rooted in a socio-psychological and theology related aspect of self-identification, with a focus on resilience.

In the media, 'radical' is usually understood as a negative aspect of someone's character or of an expressed opinion. In this line of thought, Brown (2018), referring to Neumann, states that radicalisation can be understood as 'everything that happens before the bomb goes off'. Radical statements often contain-usually simplified—verbal expressions that position the persons making them on the side of one of the extreme positions concerning the issue at stake. In the discussion on Black

1 Wiktorowicz introduces the concept of "'cognitive opening', which refers to a psychological crisis in which previously accepted beliefs are shaken and an individual becomes receptive to other views and perspectives" (in: Kundnani 2012, p. 17). (Expert Group 2008).

3 In addition to the individual and group dynamic approach, Laqueur's theological approach is mentioned with its focus on "a specific set of religious beliefs [that] is regarded as a plausible indicator of terrorist risk" (in: Kundnani 2012, p. 9). 
Peter ${ }^{4}$, for example, the media (high quality Dutch newspapers like Trouw and NRC; facebook) quote the following extreme statements that are vehemently defended by a minority of the Dutch population. 'They should take their hands off our traditions. If they don't like our traditions, let them go back to where they come from!' Or, at the opposite side of the debate: 'Only backward people believe that traditions never change and stick to Black Peter as he has always been. They should be imprisoned in their own gated communities, celebrating their own outdated festivals without bothering others.'

However, 'radical' has not always been associated with negativity. Radical is also related to the idea of a thorough and honest treatment, to the concept of going back to the untainted roots. Instead of basing our line of thought on popular or populist interpretations of 'radical', let us have a look at the roots of the word 'radical'. Radicalisation, following its Latin origins in radix, refers to going back to the beginning of what has become known as the religious tradition of Islam. Radical had the association of 'going back to the untainted roots', and subsequently an association with 'thoroughly' and 'honesty'. In that sense, the concept of radicalisation comes close to the concept of 'fundamentalism', which refers to the founding principles of a (religious or secular) worldview tradition.

Nowadays, however, in times of securitisation, radicalisation is associated with extremism (Coolsaet 2019). It is understood as a process devoid of reflection. Radical people are thought to-fanatically - accept extreme and 'easy going', in the sense of simple ways of thinking and believing.

\subsection{Radicalisation and Fanaticism}

Starting from the assumption that there is a close relationship between the concepts 'radicalisation' and 'fanatic', we follow the lines of thought of John Hull (2007) and John Renton who unravel the concept of 'fanatic' and explore the historical development of the concept. Originally, the word was used to describe someone who was possessed or inspired by a divine frenzy. It was in this way that the more modern meaning of fanaticism emerged as the 'actions, attributes, etc.' of persons insofar as they are 'characterised, influenced, or prompted by excessive and mistaken enthusiasm, especially in religious matters' (Oxford English Dictionary 1989). The word 'fanatic', like 'fundamentalist', suggests that the belief, emotion or action is excessive, inappropriate and mistaken.

The scope of the word 'radical' seems to have gradually widened and now refers to a passionate or one-sided enthusiasm and fascination, a person who devotes him/herself utterly to one single idea. Within this process, Fadil (2017) distinguishes two different layers of radicalisation. First, the layer that is visible, which is related to terrorism in the media. This layer is often seen as easy to respond to. Secondly, Fadil describes the layer that is invisible, which is difficult to notice but which needs to be monitored urgently, according to the author often referred to as a 'cancerous growth' for which we do not yet know the right treatment. In the European public discourse, both layers are seen as having a relation with Islam, with Salafism in particular. Following Fadil, they are perceived as a threat to shared values and the social cohesion of the Dutch society.

In addition to identifying issues at the micro level (e.g., failed integration, marginalisation, discrimination), an intersectional understanding of radicalisation also identifies processes at the meso level (e.g., supportive or even complicit social context) and at the macro level (e.g., lacking social recognition, lacking socio-economic opportunities) that play a role in the process of radicalisation (Schmid 2013, p. 4). In this contribution, we focus on the intersectionality of the micro and meso level. Within the scope of this article, we regard radicalisation as a gradual process that takes place in a context which makes people vulnerable to 'easy going' lines of explanation for causal relationships.

4 In the Netherlands, 'Sinterklaas' (Saint Nicholas—a Santa Claus-like figure) is traditionally accompanied by 'Zwarte Piet' ('Black Peter'), a white person painted black, who takes on the role of Saint Nicholas' assistant. Customarily, Black Peter speaks Dutch in a simplified way and often makes funny mistakes due to his misunderstanding of the Dutch language. Since the beginning of the debate about the Dutch colonial past, Black Peter has been a highly contested and vehemently discussed figure. In this public discourse, people on both sides of the debate fanatically underline their own argument. 
Following Hull's line of thought about an 'utterly devoted person', the fanatic believer is in favour of 'easy going' interpretations that take religious scriptures in a literal sense. These scriptures and other founding narratives are understood word for word and are practiced accordingly. The radical(ised/ising) believer vehemently defends her/his interpretation. Such a believer does not allow for any doubt about the interpretation of religious scriptures for today's practices. ${ }^{5}$ As stated in a report of the International Centre for Counter-Terrorism The Hague (ICCT), '... the true believer thinks (s)he is already in possession of all the answers and there is only one solution to the problem. Intolerance and self-righteousness make these persons a threat to others who do not wish to submit to their dictates' (Schmid 2013, p. 4).

What is required to challenge such a way of dealing with religious texts, according to Hull (2007), is a kind of religious education from a historical-contextual perspective, which increases the students' competency for dialogue - to stimulate dialogue aimed at 'the construction of experiential knowledge of each one's personal religious or secular worldview and life orientation. Collective endeavours crystallize different concretisations of tolerating "the other", possibly resulting in embracing "otherness"' (see also Ter Avest and Bakker 2017).

\subsection{Radicalisation and Polarisation}

In the radicalisation discourse, the aspect of safety is pivotal. 'We' feel unsafe because 'they' are a threat to employability, to social cohesion, to our culture. Fadil (2017) is interested in the performativity of the concept. What is the effect of the changed interpretation of the concept-from 'thoroughly' to 'extremely negative'? How does the concept of radicalisation poison people's minds? Fadil's suggestion is to develop methods, techniques and tools that enable us to respond adequately to the situation of plurality, abandoning the mindset of reaching for a single answer, a single narrative, a 'one size fits all' solution. She refers to Bruno Latour (in: Fadil 2017, p. 47), who stated that nowadays we do not need a set of shared values and regulations, but 'diplomats' and experts in dialogicality who can guide us on a road characterised by a plurality of value orientations and opinions.

Before turning to the dialogical self-theory, which offers a promising framework for our educational intervention that wants to go beyond the division of 'us' and 'them', we first give an impression of de-radicalisation and counter-radicalisations programmes as they have been implemented.

\section{De- and Counter-Radicalisation}

Pels and Ruyter (2011) mention three aspects that possibly influence the radicalisation process: feelings of insecurity (due to discrimination); a poor self-image (due to individual poverty/impoverished living conditions); branding as 'criminals' (because of the image of migrants in the media). Last but not least, they mention the aspect of religion: in a secularised/secularising society like the Netherlands, it is becoming more and more difficult to identify as a religious person (Pels and Ruyter 2011, p. 121). This either results in hiding away from the religious aspects in one's life, or becoming more and more interested in the religion of one's parents (Bjorgo and Horgan). The parents, the first-generation migrants, face the challenge to find a balance between adhering to the religious tradition in which they were socialised in their country of origin, and the construction of a new religious identity in adaptation to the plural and secularised/secularising context of the Dutch society (ibid., p. 122). If there is a difference or even a conflict between the socialisation in the family and the surrounding context (of the school, of society), this may stimulate a process of radicalisation. For example, a suspicious view of the parents on the Dutch educational system, which is perceived as too liberal, unjust and hindering opportunities for their children's development and accompanying later social status in society, can pave the way for radicalisation. An inclusive pedagogical approach (Florian 2015), focusing on classroom

5 In his PhD thesis, Gürlesin (2018) distinguishes between elite and popular religiosity. Participants in his research categorised as 'experiencing popular religiosity' show characteristics similar to those of fanatic believers as described by Hull (2007). 
solidarity and justice, can be expected to stimulate the development of a commitment to the democratic society. A commitment that can function as a counter-narrative to radicalisation. The school is the place where students with different ethnic and religious backgrounds meet, offering plenty of opportunities to invite students to cross boundaries during dialogical encounters (REDCo 2009, final report).

\subsection{Inclusive Pedagogy and Resilience}

In Narthex, a professional journal for Religious Education (RE) teachers, examples are given of how secondary school teachers reflect on the encounter with strict believers (Christians and Muslims), and of their inclusive pedagogical approach engaging students (at puberty and in young adolescence) in a dialogue, and to construct counter-narratives against radicalisation. ${ }^{6}$ They practice what Sieckelinck (2017) recommended in his study on radicalisation. His observation is that by asking the right questions and opening up space for reflection, teachers can invite students to reconsider the subjective theories they take for granted, while at the same time caring for their youthful vulnerability. The pedagogical strategies teachers should invest in are constantly asking questions, doing collaborative research on different sources, and guiding young people '... on their way back to where their presuppositions are rooted' (Sieckelinck 2017, p. 88). According to Sieckelinck, 'the school can be the place where cultural [and religious] identities become fluid without compromising the unique, personal identity' (ibid., p. 89). Resilience is a key word for Sieckelinck, a concept he associates with 'standing up and being counted' and 'giving a damn'. The concept of resilience must be extended to being resilient towards radical ideologies (ibid.,177), being determined to face conflicts, and awakening in oneself an attitude of 'peaceful fighting' (ibid., p. 171, 182).

\subsection{Inclusive Pedagogy-'Examples of Good Practice'}

In the text below, we give an impression of teachers' responses to classroom conversations with pupils who are named as 'at risk', as they are narrated in the professional journal Narthex. These classroom conversations in general are experienced as tense situations (Radstake 2009).

In his contribution to Narthex, 'Ontdekken van buiten en van binnen' ('Discovering on the Outside and the Inside'), Marco Otten interviewed Carla Heijtink, a RE teacher at an open ecumenical school for secondary education. This teacher is of the opinion that knowledge about the Christian tradition and the Islamic tradition is very important. 'Students should explore everything, not only the world outside themselves, but also their inner world', she states. Her motto is 'Test everything and hold fast to what is good' (Otten 2014, p. 20). Cocky Fortuin-van der Spek interviewed the RE teacher Francien Brons, who teaches at a public school for secondary education. In 'Van leerlingen kunnen houden' ('Being able to Love Students'), Fortuin-van der Spek quotes this teacher who states that by presenting a lot of knowledge and experiences to the students, they can develop their religious identity. For a period of three years, Francien Brons' students work in their 'life orientation book'. This RE teacher explains: 'In this book the students reflect on various issues and themes, and explore the meaning of all this in their own lives and in their relationships with others. This is how we establish a relationship between knowledge and the core question "Who am I?"' One of the tasks within the framework of this 'life orientation book' is to explore the core concepts of Islam together with two classmates. They have to commit themselves to the subject and work together on practical assignments. Brons explains: 'For example, they do research on the concept of jihad, and Sunnite and Shiite Islam. They read articles in newspapers in which these concepts occur; they research what kind of information is given, what image is constructed, whether the text is an informative text or if it is intended to form the readers' opinions. At the end of the day, the students need to present their findings to their classmates' (Fortuin-van der Spek 2014, p. 35). For Francien Brons' students,

6 See: Narthex, Tijdschrift voor levensbeschouwing en educatie [Narthex, Journal for Worldview and Education], Vol. 15 (2), special issue 'Addressing Current Issues: How RE Teachers Include Islam in their Classes'. 
this is a process of reflection and action—as Sieckelinck states: 'Reflection without action paralyses, because it does not encourage action; and action without reflection results in an activist attitude in a restrictive sense' (Sieckelinck 2017, p. 113). This RE teacher adjusts her methods to the age of the students, an age characterised by doing things and 'making a difference' (ibid., p. 121). The RE teacher Bill Banning, who teaches at a Roman Catholic school for secondary education, was interviewed by Ina Ter Avest. In Ter Avest's contribution to Narthex, 'Relatie aangaan door luisteren en vertellen' ('Entering into Relationships by Listening and Storytelling'), this RE teacher is quoted giving an example of his classroom practice, initiating a discussion about the meaning of having a roof over your head. Banning started a classroom discussion about feeling uprooted, out of place and alienated. He invited his students to visit places of worship, like a church, a mosque, and a temple. In smaller groups, the students gathered information and images, wrote an essay, and gave a lecture on which place of worship they preferred (Ter Avest 2014a). The next example, taken from Kees Hamers' contribution in Narthex about 'Deuren openen naar een andere werkelijkheid' ('Opening Doors to Another Reality'), is about the RE teacher Ro-Nalt Schrauwen. This teacher asked his students the question: 'Where do you encounter religion in your own context?' Students tell about buildings and about becoming engaged with persons celebrating Divali (the Hindu festival of lights) or Eid-al-Fitr (end of Ramadan). They tell about people and their lived religion - what these people believe, how they practice their faith, why they read the Bible or the Qur'an. 'I teach my students to listen carefully, engage themselves and at the same time to be critical of what they hear or read, but especially to suspend their judgment', Schrauwen says (Hamers 2014, p. 52). In this teacher's school, 'religion' is part of the final exams, with subjects like 'introduction in religion(s)', 'the Hereafter from different religious perspectives' and 'the portrayal of mankind in relation to freedom and ethics' (Hamers 2014, p. 53). Finally, in his article 'Echt in gesprek gaan' ('To Start a Real Conversation'), Taco Visser cites two RE teachers who are of the opinion that 'there is no neutrality in Religious Education'. These RE teachers, Hilde Savoye and Maarten de Vreese, who both teach at an institute for vocational training, elaborate on their favourite pedagogical approach, which is abbreviated as 'GSM'. GSM stands for Getuige (bearing witness to one's faith), Specialist (being an expert in Religious Studies) and Moderator (being a dialogical chair in classroom conversations). Savoye explains that 'a dialogical leader of classroom conversations establishes a relation between the world of the students, the contextual developments and diversity in society' (Visser 2014, p. 61). To this we can add the classroom as an embryonic society, which should also be included in this relational framework.

These real-life examples of teachers who are aware of the diversity in society and their students' life orientation in development show practicalities of responding to the threat of radicalisation. From the teachers' stories, we get the impression that their approach of doing research with their students, and facilitating the exchange of knowledge and experiences, stimulates the emergence of counter-narratives. Available research data show that 'there are many external, social factors that can push an individual towards radicalisation and there are also many internal factors than can pull him [or her!] toward a radicalised groups of peers' (Schmid 2013, p. 230). However, following this line of thought, we agree with Schmid that 'just as there are many push and pull factors on the path of radicalisation, the same holds for de-radicalisation' (Schmid 2013, p. 47). To this, we add: the same holds for the prevention of radicalisation and the construction of counter-narratives. We see the prevention of radicalisation in terms of teaching and learning through (religious and secular) narratives, resulting in the construction of counter-narratives at an individual and group level.

\section{Prevention of Radicalisation in Education}

In our view, the deradicalisation processes begin at a moment 'when it is too late to lock the stable door, because the horse has already bolted'. That is why our focus is on the prevention of radicalisation and the creation of counter-narratives. The task of education is to disrupt 'easy going' lines of thought and simplified images, to create space for reflection, to facilitate the entry of other views and to invite the pupils to postpone their judgment. This process aims at broadening young people's horizons, 
or, in dialogical self-theory terminology, at increasing their number of inner voices and making their positioning process more flexible. To achieve this educational objective, the teacher has to create disruptive moments (Ter Avest 2014b; Ter Avest and Bakker 2017) and use them as the starting point for a classroom discussion based on the principle of dialogue.

\subsection{Dialogue in the 'Society of Mind'}

A dialogue, according to Hermans

'(...) refers not only to productive exchanges between the voices of individuals but also between collective voices of the groups, communities, and cultures to which the individual person belongs. (...) It implies a learning process that confirms, innovates, or further develops existing positions on the basis of the preceding exchange. As a learning process it has the capacity to move the self to higher levels of awareness and integration. (...) Dialogue is one of the most precious instruments of the human mind and is valuable enough to be stimulated and developed, particularly in situations where learning is hampered by monological communication'. (Hermans and Hermans-Konopka 2010, p. 6)

Young people, being vulnerable at puberty and in early adolescence, can be fascinated by monological communication, by 'easy going' lines of thought. Fascination (Heimbrock 2018, p. 19) is a short-term emotion. Fascination is overwhelming, triggers the embracing of lines of thought, and yet is a transient emotional state. Fascination goes hand in hand with fleetingness. Fascination needs to be complemented with reflection, with a thoughtful detached gaze (distancing oneself from place and time). Fascination and reflection should not be seen as opposites, but as complementary. They position themselves in function of the context. In the presence of a role model with a sweeping statement, fascination will occupy a dominant position; in the presence of a teacher at school, the reflective attitude might take over the dominant position. It is in the safe space of the classroom, on the 'playground' of fascination and reflection, that students are invited to play the game of 'Wise men's chess' - an innovative and playful approach to the prevention of radicalisation and constructing of counter-narratives. Before we focus on the game in question, we will look more deeply at the aspect of resilience, because that is what we ultimately aim for.

\subsection{Resilience-Based on Dialogue}

While most studies on radicalisation explore the effects of a top-down approach, Hargreaves, in his contribution to the Journal of Muslims in Europe, researches bottom-up community-led initiatives to combat political and religious radicalisation. In his view, the problems of emerging radicalisation 'might be found as much within the realms of religion, culture, family and community as within the realms of security, policing and legislation' (Hargreaves 2018, p. 190). Hargreaves' focus is on the development of resilience, which he, referring to Ungar, defines as 'both the capacity of individuals to navigate their way to the psychological, social, cultural and physical resources that sustain their well-being, and their capacity individually and collectively to negotiate for these resources to be provided in culturally meaningful ways' (Ungar, in Hargreaves 2018, p. 202). Resilience is also defined as "the ability to bounce back from negative emotional experienes and by flexible adaptation to the changing demands of stressful experiences" (Tugade and Fredricskon 2004, p. 30, in Prince-Embury 2013, p. 10). Prince-Embury describes a variety of foci in research on resilience. First there was a focus on the idenfication of factors in the lives of persons who showed to be resilient. Then the focus was on the context, the family the child lived in. In addition to that research explored the wider context like school, being experienced as a positive or negative factor in the development of resilience. Research was also done on the description of the concept of resilience, the process of development of resilience, and on interventions designed to strengthening resilience (Prince-Embury 2013, p. 11). In this latter approach is included the promotion of positive parenting, in our case to be understood as positive teaching and learning in a safe space. 
While in the media and in public consciousness religion is often associated with radicalisation and terrorism-'without religion no radicalisation' (Sieckelinck 2017, p. 131)—Ungar brings in a different view: being part of a religious community can positively influence the coping mechanism of young people in a context of polarisation. Such religious communities provide 'a wider "weave" of inter-personal relationships; an anchor for positive self-expression; opportunities for decision-making and personal efficacy; exposure to acts of generosity; where needed, the provision of human essentials such as shelter, education and counselling; and a sense of cohesion, meaning and belonging through cultural practice and ritual' (Ungar, in Hargreaves 2018, p. 203; see also Yar 2017). These communities can be seen as safe spaces for dialogue. However, although these communities are spaces for dialogue and provide social support and other positive aspects for the development of resilience, we must not forget their role as supervisors. What is urgently needed, is for religious communities to play their part in 'withstand[ing] the destabilising effect that acts of terrorism or the threat thereof may bring about' (Dechesne, in Hargreaves 2018, p. 206). Following this line of thought, the definition of resilience should be extended to ideological resilience, which, referring to Dechesne, can be understood as 'the ability of [a] community to withstand extremist thought and to recover from extremist thought once it has become a significant part of the life of an individual or a community' (Dechesne, in Hargreaves 2018, p. 206). It is precisely on the development of resilience that we focus in this contribution. In the following section we present a case study of playful religion: a game played with groups of Muslim youth, who, as such, constitute a religious sub-community. The game fits seamlessly with what Sieckelinck (2017) calls 'liberating praxis'. In this kind of praxis, 'natality' -in the sense of making a new start-is facilitated by talking and listening, by playing and writing, and by acting and reflecting (Sieckelinck 2017, p. $95 \mathrm{ff}$ ). When playing the game, a space is constructed for dialogue and mutual exchange of knowledge and experiences, which contributes to the development of individual and group ideological resilience.

\section{The Game: 'Shatranj al- 'ārifīn'}

In modern pedagogical strategies, creative teaching and creative learning play an important role. Games can be a powerful tool to get students involved in a classroom conversation. As one of the creative and action-promoting pedagogical methods, games help students to acquire the knowledge they need in their lives-on a personal and professional level. Through playing games, students are enabled to meet the challenge of encountering different worldviews in the context of the school as an 'embryonic society'. Well-designed games help students to resolve confusing social, emotional, and religious issues. ${ }^{7}$

The Dutch anthropologist Van Baal (1972) has pointed out the similarities between games and religious rituals and ceremonies. Droogers, elaborating on Van Baal's line of thought, states that play, and playing within a safe space bounded by regulations, invites the participants to overcome "the tension between belonging and being separate, between wholeness and fragmentation" (Droogers 2012, p. 383; Huizinga 1949). Play by consequence is "a serious matter" (ibid., p. 378). Play evokes the competency to combine playfulness with seriousness, or what is more to bring together two realities or to ways of classifying, two different life orientations. In Van Baal's view, human beings have to confront the existential tension that exists between individual uniqueness and individual integration into a greater whole. ${ }^{8}$ This confrontation can be induced by inviting participants for the 'serious play' of developing a life orientation. The separated space constructed by the rules of a game facilitates in a playful way the arising of opposites at first sight and stimulates a process of active reflection about a variety of alternatives. Play by Droogers is seen as "a gift that makes us combine two ways of

\footnotetext{
(Roux 2009).

8 J. Van Baal (1972). De boodschap der drie illusies: Overdenkingen over religie, kunst en spel [The Message of Three Illusions: Reflections on Religion, Art and Play]. Assen: Van Gorcum.
} 
knowing" (ibid., p. 379). The core characteristic of play is that, due to the simultaneity of different perspectives, it urges for articulation of different approaches to reality and for a deep reflection on one's own positionality. Droogers coins this as "a stereophonic way of thinking" (ibid., p. 380). Such a way of thinking offers a way out of conflicts resulting from essentialist statements. Playfulness shows a way out of conflictuous oppositions, a way out of exclusivist reasoning. Playing creates conditions for a true dialogue (ibid., p. 386). ${ }^{9}$

The game 'shatranj al- 'ârifin', or 'Wise men's chess', is attributed to the Sufi scholar Ibn Arabi and his students in the $13^{\text {th }}$ century. Ibn Arabi's 'shatranj al- 'arifin' ' was based on an older Indian version of the game, Gyan Chaupar (Game of Knowledge). Today, it is also known as 'Snakes and Ladders' or 'Chutes and Ladders' - a game for children. ${ }^{10}$ The original game, Gyan Chaupar, teaches the Hindu spiritual path that leads to moksha, i.e., liberation from reincarnation. In this original version, there are 72 numbered squares on the game board, listing various virtues, vices, states of consciousness and planes of existence. The ladders start from squares with virtues (such as devotion) and function as 'bridges' that bring the player to the upper part of the board. Snakes are found on squares with vices (such as jealousy) and function as 'bridges' that bring the player back to the lower part of the board. ${ }^{11}$ Ibn Arabi's 'Wise Men's Chess', based on this original game configuration, was in turn used to educate and support young people in their self-chosen spiritual journey.

On the game board used by Ibn Arabi, squares of virtue were for example: faith, reliability, generosity, knowledge, and asceticism. The squares of vice or evil were for example: disobedience, vanity, theft, lying, rage, greed, pride and lust. ${ }^{12}$ As in the original game, ladders pointing upward and snakes pointing downward were depicted on the board, connecting two specific squares with their respective virtues or vices. In the game context, the virtues are understood as stimulating religious development and pulling a person upwards to their ultimate communion with the divine, while the vices drag a person down, forcing them to reflect and reconsider their behaviour. Our module uses an adapted version of this game board. The discussions taking place during the game result-under the guidance of the teacher-in an awareness among the students of their personal positioning in the field of religious and secular life orientations (in dialogical self-theory (DST) terminology: an awareness of their I-positions). Playing the adapted game (as part of the module), and entering into dialogue with other players, facilitates the emergence of a broader perspective on possible I-positions, and increases the flexibility of I-positions regarding (the diversity within) the Islamic tradition, and (the diversity within) other religious and secular traditions.

\section{Rules Defining the Space of Playful Religious Education}

The following are needed to play the game: a game board with squares denoting virtues and vices; coloured tokens; and a single die or spinning top. The original game board is shown in Figure 1. The design of the adapted version is under construction.

\footnotetext{
9 In a similar way, humour creates a space for bringing together opposite positions. This is eloquently exemplified by Amos $\mathrm{Oz}$ (2016) in a encounter with a taxi driver, described in his publication 'Hoe genees je een fanaticus' [How to cure a fanatic] (Oz 2016, p. 24). The original title of this publication, published in 2004, is 'Help us to Divorce. Isreal \& Palistine, between right and right'.

10 (Masters 2017).

11 (Bornet and Burger 2012).

12 (Bell 1983).
} 


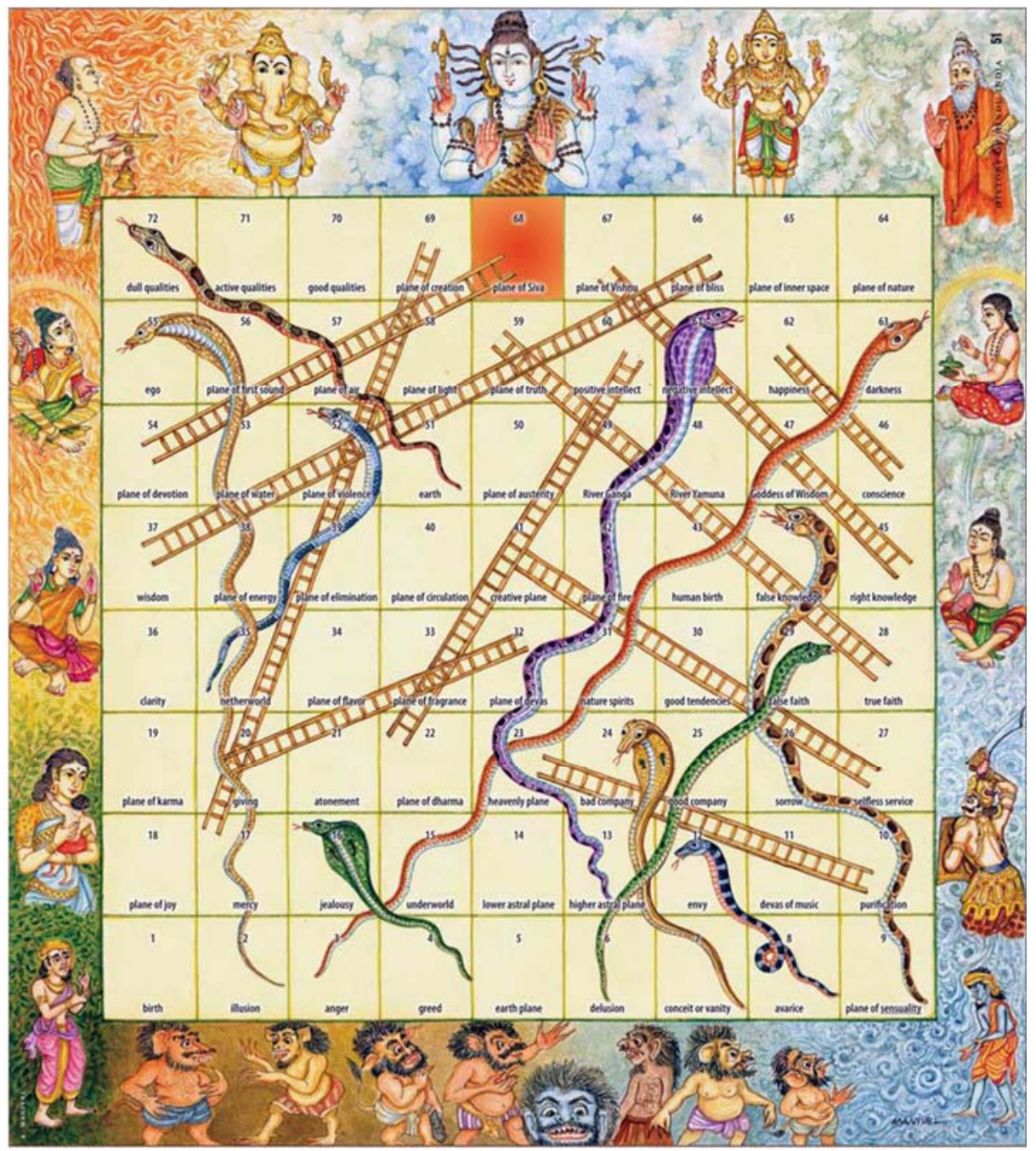

Figure 1. Original Board of the Indian Game 'Gyan Chaupar'.

The game is based on chance, on bouts of luck and bad luck, as happens in real life. It is played with 2-6 players. Playing begins on square 1 in the lower left corner. In the old days, the player threw six cowrie shells on the floor. The number of shells that landed upright indicated the number of squares that the player had to advance her/his token. Nowadays, dice are used. If the player lands on a ladder, s/he jumps to the square at the top of the ladder. If $\mathrm{s} / \mathrm{he}$ lands on the head of a snake, $\mathrm{s} / \mathrm{he}$ slides back down the tail of the snake to a lower square. The goal of the game is to land exactly on square 68 , which is at the centre of the top row. In the original Indian game, this square represents liberation from rebirth and entry into heaven. If a player lands past $68, \mathrm{~s} /$ he continues to play until reaching 72 , which takes her/him back to square 51 for another try. The game is an entertaining way to learn about making progress in spiritual and religious development. By cultivating a virtue, such as devotion, one advances. By falling prey to egotism, one relapses.

In our adapted version of the game, the virtue or vice written on the square marks the beginning of the dialogue. The player whose turn it is starts the conversation by telling about the meaning of the virtue or vice, by informing the other participants about her/his knowledge of the Qur'anic interpretation thereof, and —what is most important-by telling them about personal experiences with this virtue or vice in daily life. Questions for clarification are allowed (no judgments!), upon which the other participants tell each other about their own experiences with the virtue or vice in question. The leader of the game, an expert in Islam and DST, summarises each story in a one-liner-a short statement containing the essence of what was told. In this dialogical encounter, the confrontation with 
the one-liners that summarise each of the participants' stories is a stimulus for (further) development and for the articulation of religious I-positions in the 'society of mind', I-positions which in turn constitute the participants' religious self-narratives.

In the first round of our pilot studies, this game was played on a small scale with various groups of Muslim youth: young women, young men and mixed groups. All players, who participated on a voluntary basis, were eager to learn more about Islam, sometimes motivated by repeated questions from classmates or colleagues the moment 'Islam' became a topic in the media. Others had a longstanding wish to learn more about the tradition of their parents, noticing that their parents' religious literacy was not sufficient to fulfil their wish. The participants in the groups already knew each other for some time, which seemed important in relation to feelings of safety in the group. The game itself was enjoyed by the participants - the fun of playing a board game and throwing the dice, the laughter when someone could not wait for their turn, and the obvious excuses used by players to not have to tell about their vices. Simultaneously, the game was experienced as a safe space where justice was done to intimate narratives about virtues experienced in others, and where vices could be recognised as a disliked 'voice' in the self.

\section{Case Study—Piloting Playful Religion}

\subsection{Research Design}

There have been only a few prominent prospective or retrospective longitudinal studies in the area of religious identity development by playing. ${ }^{13}$ There have also been only a few studies where a religious/spiritual intervention was considered. In order to conduct innovative interventions to stimulate religious development, the first step is to conduct small scale pilot studies in order to get more and detailed information about youngsters' religious positioning. ${ }^{14} 15$

Before the project was fully undertaken, the choice to implement pilot exercises was made with the main aim to test the feasibility of the planned study. Specifically, the bases for undertaking the pilots were: (1) to see whether a questionnaire is effective in creating awareness positionality regarding the Muslim tradition in a plural context and (2) to test an effectiveness of the board game-can it meet our expectations regarding deep reflection on religious positionality. It was also hoped that (3) any other practical issues and difficulties could be discovered to see whether they could be resolved before the main project began.

Part of the research design is the development of a measurement instrument. We decided for 'a kind of' questionnaire, based on the dialogical self-theory (DST) and its self-confrontation method (SCM). We interviewed 11 youngsters in (early, middle and late) adolescence (age 11-14, 15-17 and 18-24 respectively) (Shweder et al. 2009, p. 18-19). Three open questions structured the interview: At what moment in your childhood did you realise you are a Muslim? At what moment(s) do you feel recognised and being appreciated because of you being a Muslim? What are your expectations for the future of being a Muslim in the plural context of the Netherlands? From these 11 interviews, 99 statements emerged, like 'I as a Muslim in the Dutch society', 'Assaults on innocent people's lives, claimed by Muslims' and 'New interpretations of the Qur'an'. This number was reduced

13 An interesting exception is an article of John W. Auxier (2018) on the use of a game in theological education.

14 Researchers have an ethical obligation to share methodological and practical issues emerging from studies done for the development and construction of scientific knowledge (Schreiber 2008). Reports on the lessons learned from and issues identified in the pilot work could be especially helpful and inspire other researchers involved in similar studies (Lanphear 2001). The principal benefit of conducting a pilot study is that it provides researchers with an opportunity to make adjustments and revisions in the proposed main study. The pilot exercise relates to identifying specific methodological and epistemological issues so that researchers can affirm, sharpen, or revise how to pursue and achieve their goals in their planned studies. We intend to use both qualitative and quantitative data collection techniques within the scope of this project. Therefore, we plan to do several pilot studies to test and improve our research design and instruments.

15 "Studies of individual cases allow the researcher to learn the intricate details of how a treatment is working, rahter than averaging the effect across a number of cases" (Kennedy 1979, in: Swanborn 1996, p. 44). 
to 18 statements using two criteria: a. similar statements were brought together in one category and reformulated into one statement, and b. distribution of typologies of religiosity among the statements according to Gürlesin (2018). Then three youngsters (a different group than the youngsters of the interviews) were asked to read these 18 statements and connect each of them with 16 different feelings, like 'doubt', 'strength', 'happiness' and 'anger'. The results of piloting this 'questionnaire' are encouraging: people recognize the statements as if they were their own statements, and they were able to connect their feelings with the statements. A short discussion after filling in the 'questionnaire' revealed that filling in already facilitated deep reflection and created awareness of religious positionality concretised in different so called I-positions. Showing the results of their scores even more made youngsters aware of and the importance of the religious part of their identity.

Another part included in the research design is piloting the board game 'shatranj al- 'ärifīn'. This part of the pilot study focusses on the second and third objectives stated above. By way of participant observation data were collected. Semi-structured interviews were conducted with some of the participants just after they played the game. Interviews, conducted in Turkish and Dutch, took 10 to 15 minutes. The authors summarized what the respondents had said and requested verification and amendments. In this pilot, member checking was also used to receive feedback on the pilot process.

The question to be answered in this pilot also concerns the match between different age groups and the degree of complexity of the game. Playing the game is part of the module-under-construction, in which young people age 15-18 become familiar with different theological interpretations of Qur'anic texts. In addition, a summary of the dialogical self-theory and its core concept of $I$-positions is presented and clarified, making students aware of the different 'roles'/'positions' they-in general and in particular regarding their being a Muslim-have in different contexts and at different moments in their life. Both of these-the theological clarification and the introduction to a socio-psychological perspective on religious identity development_aim at broadening the minds of young people and increase their literacy as a preparation for the dialogues that take place during the game. The process of broadening one's mind and acquiring a growing awareness of the variety of I-positions is strengthened by the activity of playing the game and being a partner in the dialogue. Besides fulfilling the function of knowledge transfer, playing is important to incorporate new information in existing cognitive schemes, and accordingly in the behaviour of players.

To answer the research question about the match between different age groups and the degree of complexity of the game, we selected respondents from different age groups and in different educational backgrounds. In all groups, a member of the research team took on the role of a participant-observer. This researcher also had informal discussions with the participants after the game was finished.

The last round of our series of pilot studies is carried out with six different groups during March, April, and May in 2018. The participants of the groups are members of youth groups of a mosque in the metropolitan area of The Hague and Rotterdam, religious communities that were easily accessible for two of the researchers living in that area, a so called 'convenience sample' (Etikan et al. 2016). More important for the sample choice is the fact that these metropolitan areas have to cope with pupils at risk for radicalisation. Two groups played the game in the city of Rotterdam. The first group (A) was made up of six young people aged between 12 and 18, who all attended secondary education. The second group (B) consisted of 4 tutors of the secondary school students of group A, aged between 18 and 26, all university students. Group A and B gathered at the 'Islamitisch Kennis Centrum' (Islamic Knowledge Centre) in Rotterdam. A third group (C) played the game in the city of Utrecht. Group C consisted of 18 participants, between the ages of 18 and 26. These participants gathered at the office of 'Artikel Een' (Article One; the name of the organisation refers to the first and foundational article of the Dutch Constitution). In the city of The Hague, two groups participated in the pilot (D and E). Group D consisted of six children aged between 8 and 12 ('Sociaal Educatief Kunst- en Volksacademie', SEVA). Group E (in The Hague, Ypenburg) consisted of four participants, between the ages of 12 and 16. A sixth group played the game in the city of Frankfurt (Germany). This group (F) was composed of 
18 scholars in the social sciences, adults of different ages, who were all members of the Association for Psychological and Spiritual Sciences (APSS).

\subsection{Lessons Learned from the Pilot Study}

From our observations, we learned that all the participants enjoyed playing the game. 'I think the game was really fun and instructive', one of the participants said. The participants appreciated the opportunity to have an informal dialogue about existential questions-existential questions as they arise in actual life (regardless of age). The theme of 'bad friends', for example, is discussed by young children in terms of bullying, but is seen by adults in the sense of being unreliable. All participants-regardless of their age-were of the opinion that playing the game, being confronted with others' perspectives and becoming partners in dialogue enriched their knowledge of Islam and its virtues, in relation to how they had learned about it from their parents and at school, and as far as they had heard about it before playing the game. The personal experiences of the fellow players and the dialogue that followed the exchange of narratives often proved to be an eye-opener that gave food for thought. The same held for the participants' awareness of the different 'roles' (related to I-positions) they take on or are given in-and by-society. The aspect of 'visibility' of Muslims and a positive presentation of their religiously inspired way of life in the Dutch context was extensively discussed, in particular in the age groups 18-26. A readiness for approaching the media was clearly present. In this way the game, as a central part of the module-under-construction, contributed to the religious literacy of the participants, irrespective of their age.

From the informal discussions after the gaming sessions we learned that the participants would like to change the amount of virtues/vices in the game (less for children, more for adolescents and adults), and the wording of the virtues/vices in relation to the age of the players. One player from group F, who made an appeal to the actual knowledge of each player, said: 'The meaning of the virtues might be written between brackets as a given, but we can also ask and answer each other already'. This player articulated the game as a process of collaborative knowledge construction (learning from and teaching each other/in the presence of the other).

What was further considered important was an indication given in relation to the age of the participants about the amount of time that should be spent on dialogue-the younger children could follow the dialogue attentively for only 2 to 3 minutes. As one player said: 'Assistance of a moderator or a referee in this game might help the player, and in this way the game can be continued without becoming boring or too difficult'. The adolescents and young adults (groups A-C) and in particular the older adults (the social scientists in group F) often needed more time to express their thoughts and relate their experiences in relation to a subject, and sometimes even had to be stopped to keep the game going. In the group of social scientists, the question was raised: 'Could we use this game for group therapies? Or could it at least partly be used for group therapies?' This was commented upon by the remark: 'But we must be careful, self-narratives or confessions of participants might be harmful to their amour-propre and social position'. A remark that should be kept in mind when instructing future game leaders.

\section{Conclusions, Discussion, Recommendations}

The issue we raised at the beginning of our contribution concerned the prevention of radicalisation of young Muslims, through an innovative educational intervention. This intervention is based on a provocative pedagogical approach, introduced as playful religious education, with an emphasis on an age-old game: 'shatranj al- 'arifiñ'. This game creates a safe space for young people to discuss their daily experiences with discrimination, polarisation and victimisation, and the emotions that go with this. Through stimulating awareness of their positioning process, and by helping them to develop, improve or change their I-positions, the main objective of the game is to make young people's 'societies of mind' more fluid. Through this game, students are given support to become knowledgeable about and coherent with their diverse $I$-positions, and for broadening their 'society of mind'. 
Pilot studies with the game show that students enjoy the playful way of learning from each other. They are eager to learn more about their parents' religiosity, as a result of the increasing pressure from society to take responsibility for their life orientation and their involvement in society. They are willing to explore their own positioning and that of others and are open to discussion about how positive and negative qualities play a role in their daily activities. The mutual exchange of knowledge and personal experiences in relation to the values and norms of Islam has proved to be particularly valuable. A challenge is how to familiarise students with theological 'schools' and concepts of the dialogical self-theory, without striving to make them theologians or specialists in the field of social psychology. More research is needed into a better introduction to the core concepts for students in the target age group(s).

The results of the pilot study with the measurement instrument are promising. The filling in of the 'questionnaire' on itself was experienced as an invitation for reflection and resulted in an explicitly formulated strong self-awareness as a Muslim in a plural society; a resilient attitude in unruly contexts. Young persons understood the statements and recognised them as if they were formulated by themselves. Connecting statements with feelings appeared to be a task easy to be fulfilled. Worth mentioning is that the feeling of 'doubt' was difficult to score. Also remarkable and worth mentioning is that a positive response prevailed in the scores regarding being a Muslim in the Netherlands. As a diagnostic instrument, the 'questionnaire' met the expectations.

A prerequisite for the success of the module, and of the game in particular, is that the teacher/coach performs her/his role well. Competencies like relating religious concepts to daily life, intercultural communication and the facilitation/stimulation of developmental process are preconditional and last but not least an open attitude to create a safe space for each and every pupil. As an expert in Islamic theology and heuristics, being well informed about the causes of processes of radicalisation and de-radicalisation, and well versed in the prevention of radicalisation, $\mathrm{s} / \mathrm{he}$ must also be an expert in dialogicality and the construction of counter-narratives. Such a professional must also be a provocative pedagogue: challenging the students and at the same time caring for this vulnerable age group. Last but not least, a condition that the teacher/coach must be able to meet is playfulness. A playful, light-hearted and humorous approach guarantees a positive educational climate-a precondition for the learnability of the students and their development of ideological resilience.

Author Contributions: O.G.'s focus is on characteristics of religious identity development of Muslims in diaspora; M.A. explored 'play' and the origins of the game, and is responsible for the adaption of the game; A.A. organized the pilot study; I.t.A. explored the concept of radicalisation and is responsible for the theoretical underpinning of the Dialogical Self Theory. All authors have read and agreed to the published version of the manuscript.

Funding: This research received no external funding

Conflicts of Interest: The authors declare no conflict of interest.

\section{References}

Auxier, John W. 2018. That Dragon, Cancer Goes to Seminary: Using a Serious Video Game in Pastoral Training. Christian Education Journal 15: 105-17. [CrossRef]

Bell, Robert Charles. 1983. Snakes and Ladders. In The Boardgame Book. Exeter: Exeter Books, pp. 134-35.

Conclusions. Leaving Terrorism Behind: Individual and Collective Disengagement. Bjorgo, Tore, and John G. Horgan, eds. London: Routledge, pp. 245-49.

Bornet, Philippe, and Maya Burger. 2012. Religions in Play: Games, Rituals, and Virtual Worlds. Zürich: Theologischer Verlag, p. 94.

Brown, Katherine E. 2018. Introduction: Radicalisation and Securitisation of Muslims in Europe. Journal of Muslims in Europe 7: 139-45. [CrossRef]

Coolsaet, Rik. 2019. Radicalization: The Origings and Limitations of a Contested Concept. In Radicalization in Belgium and the Netherlands; Critica Perspectives on Violence and Security. Edited by Nadia Fadil, Francesco Ragazzi and Martijn de Koning. London: Bloomsbury.

Droogers, André. 2012. Play and Power in Religion, Collected Essays. Religion and Reason: No. 50. Berlin: De Gruyter. 
Etikan, Ilker, Sulaiman Abubakar Musa, and Rukayya Sunusi Alkassim. 2016. Comparison of convenience sampling and purposive sampling. American Journal of Theoretical and Applied Statistics 5: 1-4. [CrossRef]

Expert Group. 2008. Radicalisation Processes Leading to Acts of Terrorism: A Concise Report Prepared by the European Commission's Expert Group on Violent Radicalisation. Available online: https://lib.ugent.be/ catalog/pug01:446365 (accessed on 26 July 2019).

Fadil, Nadia. 2017. Tegen radicalisering. Een pleidooi voor een postkoloniaal Europa [Countering Radicalisation. A Plea for a Post-Colonial Europe]. Brussel: VUB Press.

Florian, Lani. 2015. Conceptualising inclusive pedagogy: The inclusive pedagogical approach in action. Inclusive Pedagogy across the Curriculum 7: 11-24.

Fortuin-van der Spek, Cocky. 2014. Van leerlingen kunnen houden [Being able to Love Students]. Narthex, Tijdschrift voor levensbeschouwing en educatie [Narthex, Journal for Worldview and Education] 15: 32-7.

Gürlesin, Ömer Faruk. 2018. Elite and Popular Religiosity among Dutch-Turkish Muslims in the Netherlands. Ph.D. thesis, Leiden University, Leiden, The Netherlands.

Hamers, K. 2014. Deuren openen naar een andere werkelijkheid [Opening Doors to Another Reality]. Narthex, Tijdschrift voor levensbeschouwing en educatie [Narthex, Journal for Worldview and Education] 15: 50-5.

Hargreaves, Julian. 2018. Towards a Cure for Prevent? Building Resilience to Religious and Political Forms of Violence within British Muslim Communities. Journal of Muslims in Europe 7: 190-210. [CrossRef]

Heimbrock, Hans-Guenter. 2018. Religious Education Engagement beyond the Curriculum: Dealing with Intercultural Conflicts in Public Schools. Paper presented at the ISREV Conference, Neurenberg, Germany, July 30-August 3.

Hermans, Hubert, and Agnieszka Hermans-Konopka. 2010. Dialogical Self Theory. Positioning and Counter-Positioning in a Globalizing Society. Cambridge: Cambridge University Press.

Huizinga, Johan. 1949. Homo Ludens. Vom Ursprung der Kultur im Spiel. Hamburg: Rowohits Enzyklopaedie, pp. 17-27.

Hull, John M. 2007. The Education of the Religious Fanatic. In Peace or Violence: The Ends of Religion and Education? Edited by Jeff Astley, Leslie J. Francis and Mandy Robbins. Cardiff: University of Wales Press, pp. 46-63.

Kundnani, Arun. 2012. Radicalisation: the journey of a concept. Race E Class 54: 3-25.

Lanphear, Joel. 2001. Commentary: Pilot Studies. Education for Health 14: 33-35. [CrossRef] [PubMed]

Masters, James. 2017. Moksha-Patamu (Snakes and Ladders). Available online: http://www.tradgames.org.uk/games/ Moksha-Patamu.htm (accessed on 23 July 2019).

Otten, Marco. 2014. Ontdekken van buiten naar binnen [Discovering on the Outside and the Inside]. Narthex, Tijdschrift voor levensbeschouwing en educatie [Narthex, Journal for Worldview and Education] 15: 17-21.

Oz, Amos. 2016. Hoe genees je een fanaticus. Amsterdam: Bezige Bij bv.

Pels, Trees, and Doret de Ruyter. 2011. De relatie tussen opvoeding, socialisatie, ontwikkeling en radicalisering: een overzicht van en hiaten in beschikbare kennis. Pedagogiek 31: 117-33. [CrossRef]

Prince-Embury, Sandra. 2013. Translating Resilience Theory for Assessment and Application with Children, Adolescents, and Adults; Conceptual Issues. In Resilience in Children, Adolescents, and Adults; Translating Research into Practice. Edited by Sandra Prince-Embury and Donald H. Saklofske. New York: Springer.

Radstake, Hester. 2009. Teaching in Diversity. Teachers and Puils about Tense Situations in Ethnically Heterogeneous Classe. Antwerpen and Apeldoorn: Garant.

REDCo. 2009. Religion in Education: A Contribution to Dialogue or a Factor of Conflict in Transforming Societies of European Countries. Final report. Available online: https://cordis.europa.eu/publication/rcn/11562_en.html (accessed on 23 July 2019).

Roux, Cornelia. 2009. Innovative Facilitation Strategies. In International Handbook of the Religious, Moral and Spiritual Dimensions in Education. Edited by Marian De Souza, Gloria Durka, Kathleen Engebretson, Robert Jackson and Andrew McGrady. Dordrecht and London: Springer S+B Media B.V, pp. 1293-306.

Schmid, Alex P. 2013. Radicalisation, De-radicalisation, Counter-radicalisation: A Conceptual Discussion and Literature Review. ICCT Research Paper 97: 22. [CrossRef]

Schreiber, James B. 2008. Pilot Study. In The Sage Encyclopedia of Qualitative Research Methods. Thousand Oaks: SAGE Publications.

Shweder, Richard A., Thomas R. Bidell, Anne C. Dailey, Suzanne D. Dixon, Peggy J. Miller, and John Modell, eds. 2009. The Child. From Birth to Adolescence. An Encyclopedic Companion. Chicago and London: The University of Chicago Press, pp. 18-19. 
Sieckelinck, Stijn. 2017. Reradicaliseren: Ronselen voor een betere wereld [Reradicalising: Press-Ganging for a Better World]. Leuven: Uitgeverij Lannoo.

Swanborn, Peter Gustaaf. 1996. Case-study's - wat, wanneer en hoe? [Case Studies - What, When and How?]. Amsterdam and Meppel: Boom.

Ter Avest, Ina. 2014a. Exclusive Inclusion. Paper presented at the Symposium Diversity and the Politics of Engaged Scholarship: A comparative study in Higher Education, Bloemfontein, January 30-31.

Ter Avest, Ina. 2014b. Relatie aangaan door luisteren en vertellen [Entering into Relationships by Listening and Storytelling]. Narthex, Tijdschrift voor levensbeschouwing en educatie [Narthex, Journal for Worldview and Education] 15: 38-43.

Ter Avest, Ina, and Cok Bakker. 2017. Disruptive Moments and Normative Professionalism: An Exploration of the (Im)possibilities of Using a Provocative Pedagogy to Stimulate the Development of Normative Professionalism. In Diversity in Higher Education. (submitted).

Van Baal, Jan. 1972. De boodschap der drie illusies: Overdenkingen over religie, kunst en spel [The Message of Three Illusions: Reflections on Religion, Art and Play]. Assen: Van Gorcum.

Visser, Thomas. 2014. Echt in gesprek gaan [To Start a Real Conversation]. Narthex, Tijdschrift voor levensbeschouwing en educatie [Narthex, Journal for Worldview and Education] 15: 59-66.

Yar, H. 2017. Water en de kom: Over leven in een Turkse moskeegemeenschap in Amsterdam [Water and the Bowl. Life in a Turkish Mosque Community in Amsterdam]. Ph.D. thesis, VU University, Amsterdam.

(C) 2020 by the authors. Licensee MDPI, Basel, Switzerland. This article is an open access article distributed under the terms and conditions of the Creative Commons Attribution (CC BY) license (http://creativecommons.org/licenses/by/4.0/). 